\title{
Alpha-Ketoglutarate-Dependent Dioxygenase FTO
}

National Cancer Institute

\section{Source}

National Cancer Institute. Alpha-Ketog/utarate-Dependent Dioxygenase FTO. NCI

Thesaurus. Code C99470.

Alpha-ketoglutarate-dependent dioxygenase FT O (505 aa, $58 \mathrm{kDa}$ ) is encoded by the human FTO gene. This protein is involved in the demethylation of RNA and DNA. 